\title{
Da dimensão imagética da metáfora em Paul Ricœur
}

FELIPE AMANCIO *

* Mestrando em Filosofia pela PUC-Rio

Bolsista CAPES
RESUMO O presente texto tem por objetivo apresentar a questão da dimensão imagética da metáfora como um âmbito não estritamente verbal da comunicação. Desse modo, busca-se compreender também, com base na interseção palavra e figura, que tipo de imagens são formuladas e como elas colaboram para a construção dos sentidos nos discursos. Em vista de tal objetivo, a obra mestra que conduz tal investigação é: A Metáfora viva de Paul Ricoeur, da qual será retomado o percurso intelectual traçado pelo autor, que parte desde a antiguidade clássica, até as teorias contemporâneas sobre o tema. Tal retomada se justifica não só pela melhor exposição dos argumentos, mas principalmente por revelar a mudança de escopo das análises. Parte-se então, da compreensão de Aristóteles que pensou a metáfora como substituição de termos, de palavras, por meio de relações de analogia, deste modo, ainda restrito ao nível semiológico, até autores contemporâneos como Max Black e Nelson Goodman, que entenderam o sentido metafórico não só pela substituição de termos, mas pelas interações estabelecidas entre palavras e os enunciados nos quais estão contidas. Marca-se aqui, a passagem para a análise semântica das frases que, como os menores elementos dos discursos, possibilita a Ricoeur o estabelecimento da abordagem hermenêutica, na busca pela compreensão do sentido simbólico, e das imagens criadas nos poemas e nas literaturas.

PALAVRAS-ChAVE discurso; imagem; metáfora. 


\section{INTRODUÇÃO}

Mais do que uma simples figura retórica, a metáfora é um fenômeno da linguagem, um procedimento que utilizamos não somente para embelezar discursos, mas para nos referirmos e relacionarmos com o mundo. A metáfora cria figuras através de palavras para se reportar ao que o espirito humano vê ou sente e, no entanto, não há nome; torna clara e imprecisa a própria pretensão arbitrária da linguagem de tudo abarcar em seu interior.

Porém, nas situações limítrofes, nas quais a linguagem ordinária se mostra insuficiente, não devemos identificar uma fraqueza, e sim o que há de mais próprio à linguagem. Pois, é quando reconhecemos as diferenças e as distâncias entre o que percebemos e o que nomeamos que passamos a duvidar das palavras usadas até então. Neste momento, o mundo se revela como realidade exterior a nós, da qual, de modo insistente, só podemos dizer aproximadamente sobre.

Pode-se então identificar, em última instância, a tentativa de conexão e de comunicação da linguagem no mundo com o trabalho da metáfora que busca traduzir em seus próprios termos o que de exterior é percebido. Mas se trata aqui de uma linguagem poética, de uma experiência radical de estar no limite, de rompimento com a linguagem corriqueira. Nesse momento, não há possibilidade de conceituação. A metáfora não busca subsumir o particular no geral, mas antes, transmitir toda a grandiosidade e exuberância do mundo numa formulação precisa e única.

Por sua vez, o característico de tal formulação é a união de elementos díspares pela identificação da semelhança, sem que, de modo algum as diferenças sejam suprimidas. Entretanto, trata-se aqui da tênue semelhança dos aspectos, buscada para se costurar sentidos, e, embora a metáfora possa ser vista como um caso extremo que revela a arbitrariedade da língua, o que nos apresenta com seu jogo de palavras é pregnante, sentido como uma imagem capaz de sintetizar mil palavras de sucessivas paráfrases. Desse modo, é sobre tal imagem, obtida com a habilidade de um acrobata das palavras, que a presente pesquisa se propõe investigar. O poder, a pungência que seu uso 
adquire nos discursos que se aproximam do poético parece não conhecer limites. A metáfora sem dúvida possui uma longa história de usos e abusos, nunca deixando de retornar quer seja na fala religiosa, filosófica ou política, quer seja na poesia ou como objeto de teoria.

E nesta longa história na qual muitas obras foram dedicadas ao tema, a mais recente, que se destaca por seu grande vulto é A metáfora viva de Paul Ricoeur. Nela, o autor faz um estudo profundo da história da metáfora, investigando como esta é compreendida desde a antiguidade aos dias de hoje, num texto que já se tornou uma referência. Vê-se então o quão atual permanece o estudo da metáfora, um estudo que tem a contribuir não só à filosofia, mas todos os campos que são tangidos pelo metafórico.

\section{DA DIMENSÃO IMAGÉTICA DA METÁFORA}

O presente texto tem por objetivo apresentar um levantamento inicial sobre a dimensão imagética da metáfora como âmbito não estritamente verbal da comunicação. Busca-se compreender também, com base na intersecção parlava e figura, que tipo de imagens são formuladas e como elas colaboram para a construção de sentidos nos discursos. Para tanto, parte-se aqui dos estudos de Paul Ricoeur.

Aristóteles foi o primeiro grande autor a estudar a metáfora e suas concepções ainda reverberam com força nas teorias de gramáticos e linguistas. Para o autor, a metáfora é pensada como substituição, “[...] de uma coisa mediante um nome que designa outra coisa, \{transporte\} que se dá ou do gênero para a espécie, ou da espécie para o gênero, ou da espécie para a espécie, ou segundo uma relação de analogia." Uma questão de translação de termos, ainda muito focada nas palavras. Paul Ricoeur, por sua vez, não discorda da identificação da metáfora ao nível da palavra, mas considera que tal concepção explicita somente a dimensão da substituição.

Logo, para além da substituição de termos, de palavras, Ricoeur nos propõe uma compreensão de metáfora ao nível das frases, dos enunciados que formam o discurso. Deste modo, o sentido não é tomado como próprio às palavras, e sim como algo construído por meio de articulações. Retiramo-nos então do âmbito dos elementos da linguagem remetidos a ela mesma, e, através do estudo dos enunciados nos dire-

1 ARISTOTELES. 2015, p. 169. 
cionamos ao problema da referência às coisas, ao que a linguagem é transcendente. Contudo, é importante lembrar que compreender a metáfora em termos de enunciado, não invalida a definição clássica em termos de palavra ou nome, na medida em que a palavra continua a ser a portadora do efeito metafórico ${ }^{2}$.

Próximo desta abordagem também está I. A. Richards para quem a retórica é uma disciplina filosófica do discurso como pensamento, cujo objetivo principal é buscar o domínio das leis da linguagem, e remediar a incompreensão3 . Oposto à distinção sentido próprio e figurado, Richards mostra-se solidário a uma teoria contextual do sentido, ao entender o significado da metáfora como obtido pela interação de dois pensamentos desnivelados de coisas distintas no interior de uma palavra ou expressão simples, interação pela qual um dos pensamentos é descrito pelos termos do outro. Sendo mais preciso e, utilizando a terminologia do autor, o "conteúdo" da metáfora, pensado como ideia subjacente, é substituído pelo termo tenor, que por sua vez é transportado por um "veículo" encarregado de transmitir a ideia subjacente. Entretanto, é importante clarificar que a metáfora não é o “veículo”, e sim constituída pela união dessas duas partes.

Posteriormente, Max Black buscou desenvolver questões a respeito da distinção da comparação, se a metáfora é ou não um puro ornamento, os efeitos que procuramos ao empregá-la, assim como seu funcionamento no interior da língua. Com uma terminologia mais precisa, Black usa "focus" para se referir a palavra, e "frame" para o quadro, o contexto em que se encontra. Mais do que uma simples mudança de termos, a concepção de Black permite compreender melhor a especificidade da metáfora que, diferentemente das alegorias, enigmas ou provérbios, o simbólico não se encontra em todas as palavras, e sim “focalizado” numa só ou expressão.

No entanto, embora "foco" ilustre melhor que "veículo", a respeito do significado que certa palavra ou expressão possa ganhar num contexto, significado esse que, costumeiramente se atribui um efeito de semelhança, Black declara que a semelhança é uma noção vaga, que admite altos graus de indeterminação, e resulta mais da aprecia- 
ção subjetiva do que da observação objetiva, sendo mais interessante considerar que a metáfora cria a semelhança, do que retoma qualquer semelhança prévia 4 .

Com tal declaração Black busca eliminar o primado da semelhança, tão caro às teorias da retórica, e afirmar que não há fundamento fixo a sustentar a mudança de significado no enunciado, não havendo também razão que explique o porquê de algumas metáforas funcionarem e outras não. Por outro lado, Black tem a oferecer uma valiosa contribuição a respeito da interação palavra e enunciado, ou em seus termos: "foco" e "quadro".

Se na metáfora: “o homem é um lobo”, o “foco” sobre lobo não recai de imediato na significação lexical, no sentido corrente, é porque há um sistema de lugares comuns de uma comunidade linguística do qual a metáfora seleciona certos detalhes a fim de organizar nossa visão de homem 5 . E embora, o próprio autor reconheça os perigos de aproximar-se de noções como a de senso comum, Ricoeur relaciona tal visão a uma espécie de insight à medida que “organizar um tema principal por aplicação de um tema subsidiário constitui, com efeito, uma operação intelectual irredutível, que informa e esclarece como nenhuma paráfrase o poderia fazer.”6

E é justamente com relação de tal visão que podemos retornar a Aristóteles para quem a metáfora põe “[...] a cena diante dos olhos.” , apresenta uma visão, uma imagem que “é também uma metáfora, havendo entre elas tão só uma ligeira diferença.”. Com tais marcantes apontamentos que animam a hipótese da presente pesquisa, seguimos para o estado atual da questão com a reflexão contemporânea a respeito.

Procedendo pelo viés da semântica, Michel Le Guern ${ }^{9}$ observa na metáfora a combinação de dois fenômenos: o denotativo e o conotativo; sendo este último o responsável por criar, a partir da inserção de um termo estrangeiro, as imagens associadas que ecoam em nossa sensibilidade. No entanto, como assinala Ricoeur, esse termo estran-

4

$$
5
$$

\section{7}

\section{8}

BLACK, 1962 apud RICOEUR, 2000 p.138.

BLACK, 1962 apud RICOEUR, 2000, p. 139.

RICOEUR, 2000, p. 140.

ARISTOTELES, 2013, p. 238.

ARISTOTELES, op. cit., p. 200.

LE GUERN, 1973, p. 22. 
geiro encontra-se a serviço da coerência semântica. Surgem então questionamentos a respeito dessa imagem associada, se se trata de uma particularidade psicológica ou semântica, e como uma conotação exterior à lógica do enunciado pode contribuir para a coesão da significação.

Contudo, compreender a imagem como exterior ao enunciado só diz respeito à identificação do desvio, a identificação da dimensão figurada, e não explica como essa mesma imagem consegue, apesar de destoar do sentido literal do enunciado, contribuir para a coesão do sentido. Quanto a essa aporia, Paul Henle ${ }^{10}$ se esforçou para desenvolver uma teoria enunciativa da metáfora que compreenda os deslocamentos do sentido literal (lexical) ao figurado (criado pelo contexto); a mediação de falar algo por um sentido qualquer. Henle, por seu turno, distingue a metáfora dos demais tropos pelo caráter icônico, de modo que o discurso figurativo nos leva a pensar em alguma coisa a partir da semelhança. Porém, tais ícones não são imagens visuais, e tudo se passa na linguagem independente das associações que o espirito receptor possa elaborar.

Ciente da dificuldade em relacionar a imagem criada pelo desvio da dimensão conotativa à lógica interna do enunciado semântico, Ricoeur ${ }^{11}$ nos propõe pensar primeiramente, o modo como este enunciado se estrutura para a produção da referida imagem. Marca-se neste ponto a junção da análise semântica à análise psicológica, junção pela qual elementos lógicos (verbais) se aproximam dos sensíveis (não-verbais).

Com relação a isso, Marcus B. Hester busca pensar a especificidade do poético em oposição à linguagem convencional. Para o autor, no poético a linguagem possui um caráter mais objetual que denotativo, de modo que "olhamos para" o que nos é apresentado e não operativamente, “através”, em referência a realidade objetiva. Logo, por não denotar uma coisa ou experiência literal no mundo, e sim uma experiência interior, imputa-se a autorreferência da linguagem poética uma densidade material, um movimento centrípeto.

10 HENLE, 1958 apud RICOEUR, 2000, p. 289.

11 RICOEUR, 2000, p. 317. 
E é com relação a essa materialidade da linguagem poética que Marcus B. Hester compreende o poema como “objeto da leitura”"2. Para o autor, a leitura é um momento de suspensão do real, de abertura a sentidos criados por um fluxo de imagens compreendidas como impressões sensoriais na memória, e que revela aspectos não claros da realidade objetiva.

Contudo, o sentido icônico da metáfora não deve ser entendido como a aparição de imagens elusivas, e sim imagens ligadas, conduzidas pela dicção poética que molda o imaginário pelo jogo de palavras ${ }^{13}$. Por outro lado, apesar da admirável explicação de Richards, Ricoeur prefere adotar uma abordagem menos psicológica e mais semântica, a abordagem do "ver como".

É a apreensão do conteúdo através do veículo, por fim: o foco da visão sobre imagens especificas de respectivos sentidos. Segundo Hester, o "ver como" revela a função imaginante da linguagem, sua face sensível, e faz a semelhança emergir da união do verbal ao quase-visual.

No entanto, a visão do semelhante no enunciado metafórico não é direta, é uma visão que se dá apesar da diferença, da interpretação literal que persiste nas palavras e que se mostra falha. Tem-se então uma dupla referência. Ricoeur nos convida a investigar esse fenômeno pelo que chama de teoria da denotação generalizada em Nelson Goodman.

Goodman, em Languages of art, identifica em todas operações simbólicas verbais e não-verbais a função de denotar, de se referir. A denotação compreende as relações da imagem e o que representa, e da linguagem e o que descreve, sendo este seu primeiro movimento: ir dos símbolos às coisas. O segundo movimento da denotação consiste em exemplificar, designar uma significação como a que "possui” uma ocorrência, movimento que será explorado aqui através dos enunciados metafóricos ${ }^{14}$.

Em formulações como: o quadro que possui a cor cinza exprime a tristeza, percebemos a metáfora, e o movimento de exemplificação. Possuir o cinza, é ser exemplo de cinza, é dizer que o cinza também o denota. O quadro, por sua vez, é literalmente cinza, mas metaforicamente triste. O primeiro enunciado diz respeito a um "fato" e

12 HESTER, 1967 apud RICOEUR, 200, p. 321.

13 RICHARDS, 2001 apud RICOEUR, 2000, p. 323.

14 GOODMAN, 1968, p. 53 . 
o segundo a uma "figura", mas ambos são modos diferentes de se aplicar predicados. Goodman vê na metáfora uma aplicação insólita, de uma “etiqueta” familiar, que possui um passado, a um novo objeto, sem que a tensão de tal atribuição seja retirada.

Para Goodman ${ }^{15}$ não há diferença entre a aplicação adequada de um predicado na linguagem corrente, e a aplicação de um predicado metafórico, pois o ajuste metafórico sob um dado esquema é apreendido como ajuste literal. Contudo, ambos os casos estão sujeitos a revisões, e o literal é o que recebeu tal aval de uso. Em contrapartida, o predicado metafórico deve satisfazer exigências conflitantes como: ser inovador e adequado, estranho, mas evidente, e agenciar não só uma “etiqueta”, uma palavra, mas todo um reino de sentidos e significações que deve ser transposto e compreendido pelos termos de outro reino.

Posto isso, a respeito do fenômeno metafórico, Ricoeur escreve: “[...] se toda linguagem, se todo simbolismo consiste em 'refazer a realidade', não há lugar na linguagem em que esse trabalho se mostre com mais evidência [...]"16; quanto a Goodman, ressalta duas contribuições significativas, sendo a primeira pensar a metáfora como o princípio de transferência a todas as figuras do discurso, e a segunda, pensar a metáfora para além do domínio verbal, como no exemplo da pintura cinza, no qual a posse tal cor é ser exemplo de, é expressar metaforicamente a tristeza, uma vez que é considerada uma representação adequada.

Todavia, não se deve comprazer à vista de admirável exposição, isto é o que propõe a presente pesquisa; retomar as fontes do autor em diálogo com suas análises, e acompanhar as recentes discussões sobre o tema. Tal investigação pode beneficiar não só os estudos filosóficos, no que o metafórico tem a auxiliar a criação de conceitos, mas também os estudos literários, artísticos, e todos os outros que sintam a necessidade de outras formas de comunicar, quando as palavras parecem pouco em relação ao que se tem a dizer.

15 Ibidem, 1968, p. 78.

16 RICOEUR, 2000, p.362. 


\section{REFERÊNCIAS BIBLIOGRÁFICAS}

ARISTÓTELES. Poética. Tradução de Paulo Pinheiro. São Paulo: Editora 34, 2015

.Retórica. Tradução de Edson Bini. São Paulo: Editora Edipro, 2011

BLACK, Max. Models and Metaphors: Studies in Language and Philosophy. Ithaca: Cornell University Press, 1962

GOODMAN, Nelson. Languages of Art, an Approach to a Theory of Symbols. Indianapolis: The Bobbis-Merril Co, 1968

HENLE, Paul. Language, Thought and Culture. Ed. Paul Henle. Ann Arbor, University of Michigan Press, 1958

HESTER, Marcus B. The meaning of poetic metaphor. The Hague, Mouton, 1967.

LE GUERN, Michel. Sémantique de la métaphore et de la métonymie. Paris: Larousse, 1973. RICHARDS, Ivor Armstrong. The Philosophy of Rhetoric. Oxford: Oxford University Press, 1965.

RICOEUR, Paul. A metáfora viva. Tradução de Dion David Macedo. São Paulo: Editora Edições Loyola, 2000. 